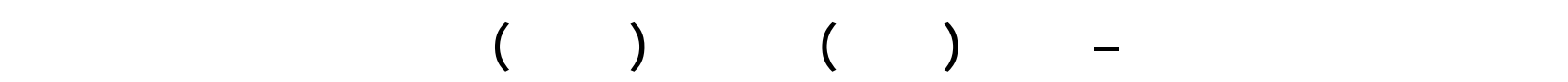 الأنزيمية وغير الأنزيمية وبيروكسة الدهن في ومطل وأنسجة نكور الجرذلن البيض
}

\author{
عسرلب يحيم الفلم \\ مف هسبن جانكير \\ قمم علوم الحية \\ كلية العلوم \\ جلمعة الموط
}

(تاريخ الاستلام 17/ 6 / 2009 ؛ تاريخ القبول 15 /2 / 2010)

\section{الملغص}

تضضمنت الدرلسة الحالية التعرف على مدى التأثير للسهي لمبيدي الألفا -مثرين لجس ـيرين) والأكت ارا

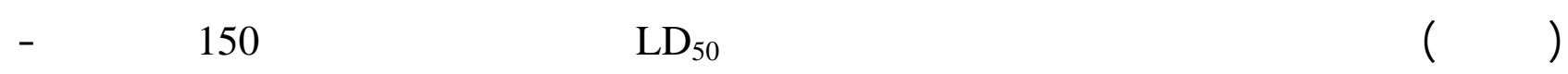

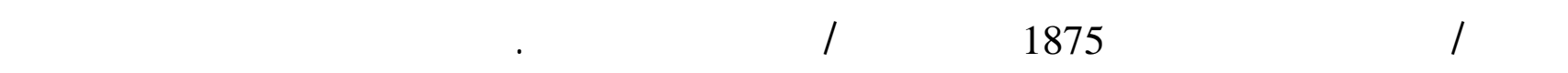

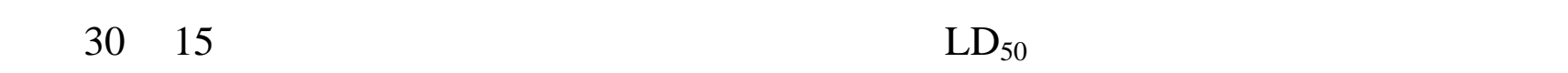

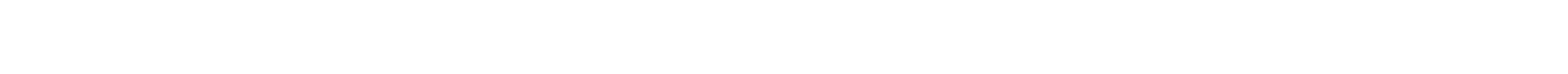

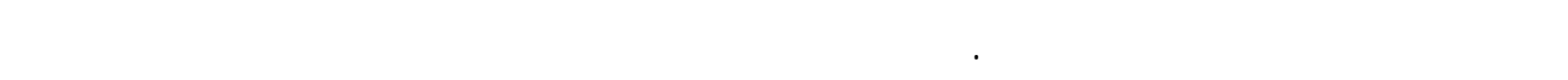

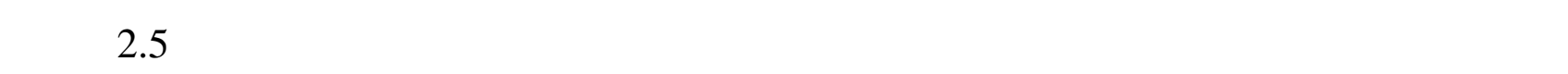

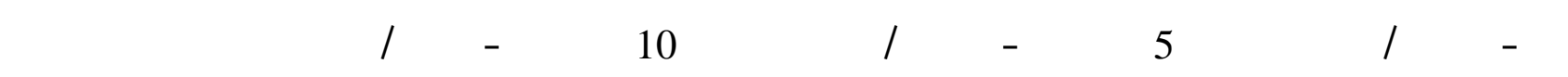

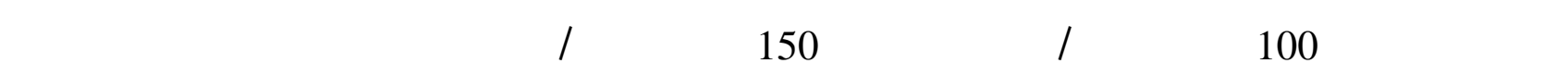

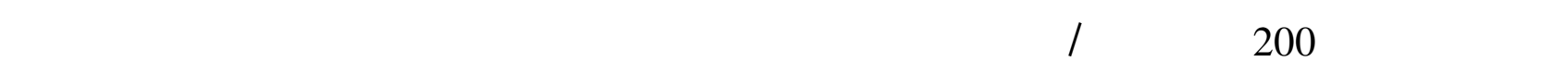

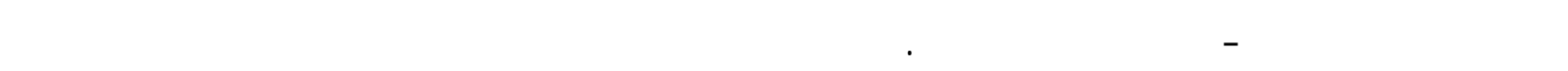

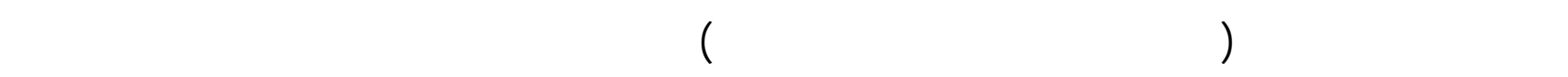

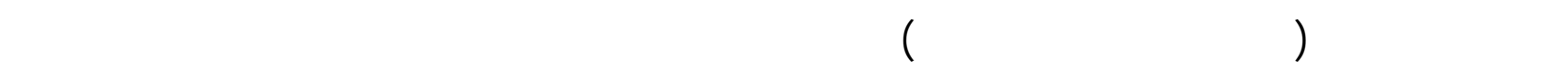

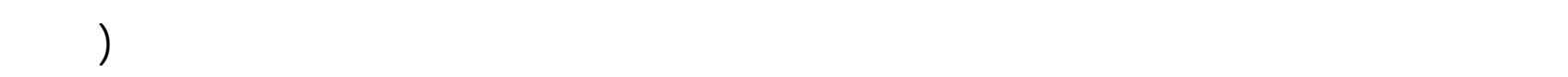

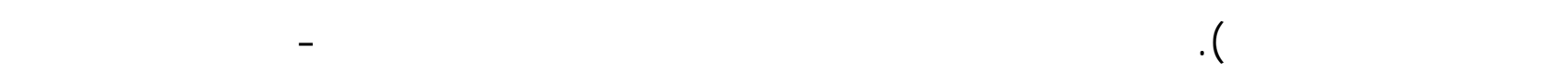

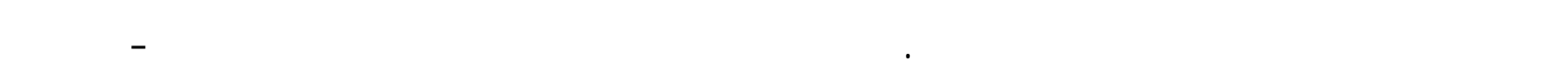
يمتلك تأثيراسميا لكثر من مبيد الأكتارا. 
من عسين جانكير وسرراب يحيى القلبم

الكامل الدالة : الألفا -مثرين (سيرين)، الأكتارا (لكروزير)، الكلوتاثيون، المالونداليالنيهايد،سوبر وسئر أوكسايد

مسميوتيز·

\title{
Comparative Effects of Alpha - methrin (Serin) and Actara (Cruzer) Insecticides on some Enzymatic and Non-enzymatic Antioxidants and Lipid Peroxides in Serum and Tissues of White Male Albino Rats
}

\author{
Muna H. Jankeer Sarab Y. Al-Qassim \\ Department of Biology \\ College of Science \\ Mosul University
}

\begin{abstract}
The present study included the recognition of alpha-methrin (Serin) and actara (Cruzer) insecticides medium lethal dose $\mathrm{LD}_{50}$, which was found to be $150 \mathrm{mg}$ alphamethrin/Kg body weight and $1875 \mathrm{mg}$ actara / Kg body weight. By consideration of $\left(\mathrm{LD}_{50}\right)$ values three doses of each insecticide were orally administered to male albino rats for 15 and 30 days period, to study their effects on the levels of some enzymatic, non enzymatic antioxidans and lipid peroxides in serum and tissues of albino rats.

The rats were divided into 7 groups; the control group which administered with distilled water, the first to third group were administered with $2.5,5,10 \mathrm{mg} / \mathrm{Kg}$ body weight alpha-methrin respectively, the fourth to sixth group were administered with 100, 150, $200 \mathrm{mg} / \mathrm{Kg}$ body weight actara respectively on comparison to control group with that treated with either alpha-methrin or actara. The results showed a significant decrease in non enzymatic antioxidant (uric acid concentration and glutathione) level and an increase in the activities of superoxide dismutase (enzymatic antioxidant) and a significant increase in malondialdehyed level in serum blood of rats treated with either alpha-methrin or actara. The results also showed a significant decrease in level of glutathione accompanied with significant increase in malondialdehyed level in tissues of (brain, heart, liver and kidney). The rats which administered with different concentrations of alpha-methrin insecticide, showed more effects than that groups administeared by actara. These results indicated that the alpha-methrin has more poisonous effects than actara insecticide .
\end{abstract}

Keywords: Alpha-methrin (Serin), Actara (Cruzer), Glutathione, Malondialdehyde, Superoxide dismutase. 